\title{
Learning to Implement Teaching Games for Understanding During Teaching Practice 學習在實習期間實踐領會教學法
}

\author{
Alberto CRUZ \\ 高達倫 \\ Chung LI \\ 李 宗 \\ Kevin Wai Keung KAM \\ 甘偉强 \\ Department of Health \& Physical Education, \\ The Hong Kong Institute of Education, HONG KONG \\ 香港教育學院健康與體育學系
}

\begin{abstract}
The purposes of this study were to examine the process of learning to teach TGfU and the factors that influence student teachers to implement this approach during the teaching practice. 23 secondary student teachers who intended to try the approach in the teaching practices were purposely invited to take part in the study. Passive participant observation, formal and informal interviews, journal writing and document analysis were used to collect qualitative data. Data were organized and analyzed through inductive analysis and constant comparison. The participants equipped the knowledge of application of the TGfU through various learning channels: Trial teaching, observation of peer teaching and discussion among colleagues. Post-lesson reflections also helped to refine their practices. They spent much time in lessons preparation. They adopted "start and end with a game" lesson format and used facilitated questions between the game activities. Students, teaching experience, preparation, class management, school facilities and support were major factors influencing the implementation of TGfU. They emphasized the importance of the experiences of implementation and the post-lesson reflective process within the learning to teach process. Findings of the study hold implications for the practice of physical education teacher educators with respect to the learning to teach TGfU process.
\end{abstract}

摘 要

本研究目的是探討學習教授領會教學法及影響實習老師於實習時實踐領會教學法的因素。二十三位實習老師參與是次研究。 透過被動參與式觀察、正式及非正式訪問、老師反思日誌及文件分析等方法收集數據。然後以持續比較法分析資料。結果顯示實 習老師透過不同學習模式掌握應用領會教學法知識。影響實習老師實踐領會教學法因素包括學生、教學經驗、準備、課堂管理、 設施及支援。此等結果給予體育師資工作者培訓領會教學法多方面啟示。 


\section{Introduction}

To develop student teachers to become competent and effective teachers is one of the major goals of teacher education programmes. However, learning to teach is a complex process (Jalongo \& Isenberg, 1995) and the best way to equip student teachers to teach competently in diverse contexts is not known. Cochran-Smith and Lytle (1990) argue that teachers learn to teach by teaching and student teaching has played an important role in learning to teach process. Student teachers learnt more of what they need to know during teaching practice than from their coursework. They also changed and became more reflective once they started their teaching practice (Brown, Cooney, \& Jones, 1990; Lee, 2005). Teacher educators agreed that student teachers should be engaged in reflection if they are to emerge from the student teaching experiences as competent practitioners. Reflection upon teaching practice has become one of the major focuses of teacher education as it will enhance teaching ability and learning to teach (Cochran-Smith, Garfield, \& Greenberger, 1993). Therefore, the theoretical rationale for this study is based on theories of reflection in learning to teach.

Advocacy for reflection in teacher education programmes is based on the acceptance of the complexity of teaching. Teachers cannot be prepared for every situation they may encounter, it is preferable to help them become reflective practitioners (Tsangaridou \& Siedentop, 1995). It is assumed that student teachers can learn to be reflective and become critical within this context (Placek \& Smyth, 1995).

Moreover, according to the constructivist view, student teachers develop their professional knowledge in a process of reflection on practical situation. Korthagen (2001) identified that field experiences offer optimal chances for growth of reflective skills and inquiry-oriented activities. Therefore, student teachers must be initiated in the practice of learning to reflect before they begin their student teaching experiences and they must be guided in structured reflection process during teaching practice. To enhance learning to teach ability, Darling-Hammond (1998) asserted that prospective teachers must study research and conduct their own inquiries through cases, action research, and structured reflections about practice. Physical education teacher educators identified that a variety of specific strategies have been used to enhance the reflective capabilities of student teachers during field experiences: writing, curriculum inquiry, supervisory approaches, action research, enthnography, and reflective teaching (Tsangaridou \& Siedentop, 1995). The writing of journals, logs, logbooks and portfolios are other common strategies to encourage reflection (Melograno, 1998; Senne \& Rikard, 2004).

The Health and Physical Education Department of the Hong Kong Institute of Education also advocates the practice of reflection during the teaching practice. The physical education student teachers are required to conduct lesson reflection after each lesson teaching. At the end of the teaching practice, they are also required to write an overall reflective journal with reference to their teaching practice experiences. By encouraging student teacher in meaningful reflection, they can better evaluate and improve their own teaching performance by linking theory to practice. In short, reflections on practice of teaching are essential part of learning to teach process of student teachers during the teaching practice. Glenwright (2001) commented that reflective model was likely to have an important role to play within the Hong Kong Institute of Education field experience component.

Teaching games for understanding (TGfU) (Bunker \& Thorpe, 1982) has been considerably received attention all over the world in the past two decades. It is widely accepted as the appropriate approach for teaching games in physical education lessons. This approach offers a natural and game-oriented setting to learners. With the facilitating role of the teachers, students enhance their understanding and learning. Griffin, Brooker, \& Patton (2005) comment that TGfU can be regarded as an innovative approach in teaching and learning of games. This innovative approach has been included as the teaching content of curricular and pedagogical modules within the physical education teacher education curriculum of the Hong Kong Institute of Education in recent years. Physical education student teachers are encouraged to practice this approach during the teaching practice. However, researchers identified a number of hindrance factors and contextual constraints that teachers might experience when they learned to implement the innovative curriculum models (Cruz, 2004; McCaughtry et al., 2004; McNeill, et al., 2004). It is likely the student teachers may experience difficulties when implementing TGfU during the teaching practice. In fact, student teachers perceived the approach might have limitations in implementation when they first learn the approach during 
the method module (Wang \& Ha, 2009). Some student teachers even claimed that they were not well equipped to apply this approach during the teaching practice ( $\mathrm{Li} \&$ Cruz, 2006). Therefore, it is worthwhile to understand how the student teachers learn to implement the TGfU. The purposes of this study were two fold. First, to examine the process of learning to teach TGfU of the student teachers. Second, to understand the factors that influence student teachers to implement TGfU approach during the teaching practice.

\section{Method}

23 final year secondary physical education student teachers who intended to try the TGfU approach in their teaching practices were purposely invited to take part in the study. The participants were videotaped and observed teaching two physical education lessons adopting the TGfU approach during the teaching practice. Field notes related to the teaching and learning activities of TGfU were recorded during the observation. The investigators conducted informal interviews and formal interviews with the participants during and after the teaching practice. This information helped to understand the participants' beliefs and knowledge about the contents they teach, their preparation and their experience of implementing the TGfU approach. The participants were also asked to give copies of unit plans, lesson plans and reflections after each TGfU lesson as well as a reflective journal of their experience of implementing TGfU during the teaching practice. The analysis of these data was based upon the methods of inductive analysis and constant comparison and coding procedures (Glaser \& Strauss, 1967; Strauss \& Corbin, 1990). Through inspection and careful reading of the data, themes were identified within the data. The investigators sought for the dominant trends and patterns within the study as a whole. The investigators utilized several strategies to establish the trustworthiness of results: triangulation, peer debriefing, and member checks.

Findings from interviews, lesson observation, document analysis and reflective journal writing were compared and cross-check as to confirm its accuracy and interpretation. Data triangulation from different participants, collected in multiple methods and times enhances findings reliability (Cohen, Manion, \& Morrison, 2000). In addition, an experienced qualitative research colleague was asked to read and comment on the preliminary analysis and interpretation of the data. Meetings were then held among all investigators and discussed to accept a final agreed interpretation and analysis. Peer debriefing supports the credibility of the data and established the overall trustworthiness of the findings (Lincoln \& Guba, 1985). Lastly, the participants were asked to read the interview transcripts and field notes to verify accuracy. Only minor changes were made accordingly. Member checks also establishes the credibility and validity of the data collected (Silverman, 1993).

\section{Results}

The analysis of the data helped to understand the learning process of the student teachers in implementing the TGfU and the factors that influence their implementation during the teaching practice. The following sections presented how the student teachers learned to teach and implement TGfU as well as the factors affecting the implementation of the approach.

\section{The Process of Learning to Teach TGfU}

\section{The Learning of TGfU}

Student teachers are assumed to have acquired basic subject knowledge and professional skills before their teaching practice. The participants in the present study had attended curriculum, methods as well as teaching games for understanding modules in physical education: 30 hours curriculum design in secondary physical education, 30 hours teaching methods for physical education in secondary schools and 30 hours teaching games for understanding. They were equipped the basic curriculum knowledge, teaching skills, theories and format of teaching games for understanding from the modules. Besides, they were given peer teaching experiences in conducting physical education lesson and teaching games for understanding approach. Student teachers are expected to learn TGfU well before they implement the approach. Findings indicated that the participants did equip the knowledge of application of the TGfU through various learning channels:

a) "Learning by Doing" - It is assumed that certain teaching skills were best learned through directed laboratory practice and extensive practical experience in real settings. In the present study, the student teachers emphasized the importance of the learning experiences within the physical education teacher 
programmes. They claimed that they had acquired the basic knowledge and concepts of TGfU approach within the curriculum and methods modules and the TGfU module before the teaching practice. By participating in the lectures' learning activities, the student teachers learned the design of games activities and planning of TGfU lessons. They admitted that they learned how to work out TGfU lesson plans through learning activities in the modules. The peer teaching experiences in the TGfU module were remarked as invaluable and helped them to get familiar to the TGfU teaching and learning format within a physical education lesson. Below were some of the views on TGfU learning:

"I understand how to plan a TGfU lesson through collaborative work with my colleagues in the lectures...”

"...for example, I learn how to design appropriate games that related to my lesson objectives..."

"I think I have learned how to design and use appropriate questions in the lessons within the TGfU module."

"We have practical experiences in trying out our designed work through peer teaching..."

"...the lecturer provided opportunities for us to try out a designed TGfU lesson ..."

b) Social Learning - People may learn through observation and modeling (Bandura, 1986). The student teachers learned to implement the TGfU approach by observing the trial teaching performance of their peers and sharing ideas with their peers in the group discussion activities within the lectures. They underscored what they saw in the peer teaching and learning ideas of colleagues during the discussions helped their implementation of TGfU. The participants described what they learned from their peers:

"I seriously considered the comments and ideas given by my colleagues, and I find most of them are useful for implementation in real class teaching." "Most of the activities designed by colleagues are generally good and practical; they are useful and can be my references in my TGfU lessons."

"How my colleagues teach TGfU during the peer teaching sessions give me a concrete picture of conducting a TGfU lesson, I can copy some of these teaching and learning activities as my trial in TGfU during the teaching practice." c) Problem Solving and Reflection -Teachers always affirm that "experience is the best teacher" (Goodlad, 1984). However, experience alone does not guarantee the improvement of practice. It depends on how we make use of the experience gained. Researchers have identified critical reflection upon experience is a valuable process and problem solving method for teachers to implement and test the selected solution in professional practice (Attard \& Armour, 2006; Copeland, Birmingham, de la Cruz, \& Lewin, 1993; Mayes, 2001). The student teachers in the present study demonstrated that they had reflected and learned in the modules' learning activities:

“...the lecturer facilitates our reflection on the peer teaching practice experiences...through discussion, we understand more about the implementation..."

"I think post lesson reflection during the teaching practice is very important, it helps my further practice...I usually improve some of my practice after taking serious reflections..."

However, student teachers usually had some problems when they first tried the innovative teaching methods during teaching practice (Gurvitch, Blankenship, Metzler \& Lund, 2008). The participants in the present study are no exceptions; they also encountered difficulties when implementing the TGfU approach. Some were able to deal with the problems and search for solutions by themselves. They read related reference materials and sought help from others. Some learned to polish their implementation through post lesson reflections. They consolidated their TGfU teaching and eventually successfully solved the problems and implemented the approach. The following were some of the approaches how the student teachers handled their teaching difficulties during the teaching practice:

"I would seek advice from the cooperating teacher and supervisor. They usually could give me some feasible ideas."

"I usually seek help from my colleagues who had tried the TGfU. We discuss and try to figure out some possible solutions."

"I will read more references and make use of the internet and see whether there are some examples of solving the problems." 


\section{The Implementation of TGfU}

Physical education student teachers in the Hong Kong Institute of Education were encouraged to apply innovative teaching methods during teaching practice. Participants in the present study chose to apply TGfU approach in teaching games lessons. Data reviewed that the participants implemented the TGfU approach in various teaching stages during teaching practice:

a) Preparation - Good preparation will help teaching performance during teaching practice. The student teachers were advised to spend time in preparing their lessons before their teaching. The participants in the present study planned their TGfU lessons seriously. Most admitted they had spent much time in their lesson preparation. They made used of the teaching notes, TGfU texts and web materials in designing the TGfU learning activities. Some discussed with their colleagues in preparing the lesson activities. Progressive situated games and facilitated questions were commonly designed and adopted for the approach. Below were some of the ways the participants prepared their TGfU lessons during the teaching practice:

"First, I considered those I had learned in the TGfU module..."

"I revised those reading notes during my preparation".

"During my planning, I read some TGfU reference books..."

"I made use of the internet to help my TGfU lesson planning..."

"I sought comments from my supervisor or discussed my ideas with my colleagues"

"...I tried to seek comments and ideas with my colleagues to see whether my ideas are feasible".

"I tried to plan progressive games and questions for the TGfU lessons..."

"I have used situated games to facilitate their learning in games concepts..."

b) Delivery - How the student teachers presented the teaching contents and learning tasks in the TGfU lessons directly implied how well they applied the TGfU approach. The participants mainly used situated games and questioning strategy in the TGfU lessons. Field notes data confirmed that they adopted "start with a game and end with a game" format in their practice. Questions were used to facilitate students' cognitive development and some allowed discussion time for the students to explore the solutions. Most participants were able to modify the facilitated questions and games to enhance student learning. Progressive competitive games and games format of 1 vs 1,2 vs 2 and 3 vs 3 were commonly used in the lessons. The participants mentioned how they delivered the TGfU lessons:

"I would use questions to guide their learning and playing in the games activities..."

"I expect they would solve the problems themselves. That is...I use questions and they need to sort out the answers themselves. I only facilitate their learning."

"Games like 2 vs 2,3 vs 3 and 6 vs 6 were used..."

"They had warm up activities first, then they had games; after the games they might have discussion or Q\&A. They played game again. I adopted the cyclic format."

However, some student teachers were inexperienced in applying appropriate questions and games in the lessons. They claimed the students' responses were not good. "When you asked some questions and they could not answer, it seemed the students did not learn anything..." Field notes data indicated that some participants might have problems in designing progressive games and using suitable facilitated questions in the TGfU lessons. The following episodes were extracted from the field note data: "The designed game might not be appropriate and some students did not want to take part..." "The games adopted did not match the games concepts to be taught... besides, the questions were few and superficial and did not lead to higher order thinking...The teacher did not further prompt the students to answer the questions." (Field notes)

c) Post Lesson Reflection - Reflection guided practice of teaching (Tsangaridou, 2005). The participants in the present study were required to conduct post lesson reflection during their teaching practice. The major purpose of reflection is to help student teachers to self-evaluate and improve their practice. Data from document analysis indicated that the student teachers reflected according to the teaching and learning of TGfU approach in the lessons. Much of their reflections were based on the learning 
responses of their students within the TGfU lessons. Below were some of the post lesson reflections of the participants:

"Students were not willing to play the modified game; I should make the games easier..."

"The students actively took part in the learning activities. Most of them participated in the designed games, some even voiced out and wanted to lengthen the playing time."

"...I found that the students were actively involved in the activities, even the low skilled students were able to find their positions in the games and competitions. They were relatively more active than before in the PE lessons." “...the learning atmosphere was good and the students were able to give my expected answers"

"...the students did not want to take part in the games and they commented the activities were too simple and not challenging..."

"Most students did not want to respond my questions after the games activities; however, they were comparatively more involved and enjoyed the activities. The student participation in the activities was high."

The students' learning responses seemed to be the major criteria for the participants to consider for further improvement of the implementation of TGfU approach. The post lesson reflection data of the participants indicated that most student teachers were tackling the teaching difficulties earnestly and thoughtfully. Some of the teaching difficulties were raised:

"...if we want to make the lesson success, we have to carefully consider the student numbers, group allocation, student ability and sport ground using factors etc..."

"...in order to help them learn, we need more experience in implementation and preparation...only we have more trials and I think the TGfU could help the students."

"I tried to modify and simplify the games, and maximize the using of playground. The learning outcomes had much improved..."

However, not all student teachers were able to handle the teaching problems properly; few did not spend much time in solving the problems and eventually gave up adopting the approach at the end. Some responded negatively in the reflection journals:

"...after the first failure experience in implementation,

I decided to give up this teaching approach."

"In reality, not all students in my class had good learning attitude in physical education lessons. Having some low motivated students, it was hard to continue the question part after the games; I did not know what to do..."

"If we have limited space in school, it is hard to allocate all groups to have games at the same time...”

Nevertheless, the teacher preparation programmes for learning TGfU were well perceived by the student teachers. They acknowledged that they had learned the implementation of TGfU well in the TGfU and methods modules. From their post lesson reflection, it seemed what they had learned was insufficient to handle the difficulties faced during the teaching practice.

\section{The Factors Influence the Implementation of TGfU}

Implementing innovative approach during teaching practice is not easy task for student teachers. A number of factors have been identified affecting student teachers and teachers first implementing the TGfU approach (Cruz, 2004; McNeill, et al., 2004). The participants in the present study reported that several factors had influenced their implementation of $\mathrm{TGfU}$ during the teaching practice:

Student - Student was mentioned as the major determinant factor that affected their adopting of TGfU. The students' classroom behaviours and learning attitude were important criteria they considered whether to adopt the approach. The participants treated low motivated students as a kind of hindrance on their implementation of TGfU approach. They pointed out that these students were reluctant to participate in the learning activities and they did not know how to handle these students:

\footnotetext{
"...the most difficult part is the low learning attitude of the students; they did not want to take part in the games activities..."

"...the girls did not like the games lessons and they did not want to move."
} 
Moreover, student learning behaviours in the lessons might also exert negative influences on their implementing of innovative methodologies. Student teachers indicated classes with behavioural problems were not suitable for TGfU lessons:

“...during my second teaching practice, the students that I taught had many disciplinary problems..."

"TGfU only suits for those students with highly selfdiscipline and self awareness students..."

"First, the students need to behave properly in the lesson and I feel comfortable in adopting the approach...otherwise..."

On the other hand, the participants would adopt the approach if they find the students with good learning attitude:

"When I find the students were used to actively participate in the activities and I definitely will try the TGfU approach...”

Teaching Experience - Most participants tried the approach during their second teaching practice as they had no confidence at the first teaching practice. Some claimed that they were unfamiliar with the teaching environments and chose to try the direct teaching strategies during the first teaching practice:

"I did not try the TGfU because I had no confidence in my teaching."

“...as this was my first teaching practice, I was afraid that I could not control the class discipline at that time..."

"I was a little bit scared of my first teaching practice as I did not have any teaching experience."

After gaining in field teaching experience, more student teachers were willing to try the innovative teaching methods during the second teaching practice. Some said that they would like to try the innovative methods because they had positive TGfU teaching experience during the first teaching practice:

"I had confidence in applying the TGfU as I had good experience in the first teaching practice."

"I would like to adopt the approach again as the students were learning very well during my first trial."
In fact, some said they gained more teaching experience in the first teaching practice and they wanted to try some innovative methods before they graduate:

"As I had not tried any innovative strategy in my first teaching practice, I would like to try the TGfU approach during the second teaching practice."

"...the institute always encouraged us to try the innovative teaching methods, so I realized the second teaching practice was my last chance to adopt the TGfU approach before graduate."

Preparation - Most participants voiced that they had difficulties in games designing, questions setting and responding students' answers in the lessons. They also commented that they did not give good performance within these three perspectives during the teaching practice. It seemed that the participants did not prepare well before the lesson. In fact, some raised designing appropriate games for the students was not an easy task. They further that they were not sure whether the games they designed matched the games tactics to be learned:

“...the most difficult part was to design appropriate games in the lessons; it might take me much time..."

"...I wonder whether the games I introduced would help the students learn the tactical concepts I prepared..."

"...yes, I had problems in finding games for the students, besides, I did not know whether the students would like these games..."

Moreover, the student teachers admitted that they did not ask good facilitated questions after the games. They were aware that they would need much improvement in preparing stimulated questions in the lessons:

"...I think I did not do well in designing good questions in the lessons..."

"I need to improve my questioning skills and questions. The questions that I prepared were too superficial...I think I need some time to learn how to ask and set good questions."

"I find that I did not ask my questions properly and the students could not answer my questions; I wonder whether the students had learned anything..." 
Few participants also indicated they did not have much experience in responding unexpected answers from the students. It was rather difficult for them to guide the students back in answering the original questions. Below were the problems concerning responding to students mentioned by the participants:

"...it is hard for me to add or modify some questions instantly and help their learning in the lesson...”

“...you might have some irrelevant responses from the students; I did not know how to deal with these answers..."

"...sometimes, I did not know how to guide the students to answer my questions if they responded differently."

"I planned some questions to guide the students; however, the responses from the students were sometimes far from my expectation..."

The student teachers did have some difficulties in preparing the lessons. Helping them to prepare well before their TGfU teaching might help their implementation of the approach.

Classroom Management - Some participants had problems in controlling the flow of the teaching lesson, while some had difficulties in organizing the learning activities as well as managing the lesson time. It seemed that some student teachers were still unfamiliar to the teaching environments and lacked proper management skills in teaching TGfU. Here were the views on class management by some participants:

"If I had forty students, I might have management problems when adopting TGfU."

"My major difficulty was to manage students and classroom orders..."

"...my major problem was the lesson time was too short...I think I spent much time in organizing games activities."

Field note data indicated that student discipline problems might also affect the flow of the TGfU lesson. "...the games were not special and they did not arouse the interest of the students. Due to the poor presentation of the games activities, some students did not know how to play the game. Eventually, the students' off task and misbehaviors affected the flow of the lesson..." "...most of the time the students were shooting basketball and these were not the requirements of the teachers. The overall reaction of the students led to classroom management problems. It seemed that the teacher was not preparing well for the lesson and he did not know how to deal with such student misbehaviors..." (Field notes)

Managing classroom ability of the student teachers directly influences their confidence in adopting the TGfU approach.

School Facilities - Some participants reported schools with limited space area were not suitable for the implementation of the TGfU approach. They pointed out that sufficient school facilities was one of the major contextual requirements when implementing TGfU approach:

"The most difficult part was space using as the school had only one basketball court..."

"My practicing school did not have sufficient space and could not cater large class size in PE lesson; besides, limited sport ground was another problem in conducting TGfU..."

"I think limited school facilities might be a major restriction for TGfU lesson; the playground might not have sufficient space for games activities..."

However, not all secondary schools in Hong Kong would have sufficient sport ground and space for conducting TGfU lesson. The student teachers are expected to tackle this practical problem during their practice of teaching.

In real practice, some student teachers were unable to handle this practical teaching issue and eventually gave up the approach.

Support - Student teachers are unfamiliar to teaching environments and will face various difficulties during the teaching practice. Most are in need of practical and emotional support (Murray-Harvey et al, 2000). The participants in the present study are no exceptions. Most found that they had some problems when adopting the TGfU approach. They claimed that supervisors and cooperating teachers had played important roles in assisting them in carrying out innovative approaches. Positive encouragement and feasible advices were invaluable to them. If supervisors and cooperating teachers were familiar 
with TGfU approach and could help them to solve the problems arised from TGfU teaching, they would definitely have more confidence to adopt the approach. Below were the views of participants on the roles of supervisors during the teaching practice: "Due to the encouragement of my supervisor, I tried the TGfU approach in the teaching practice. His fully support gave me much confidence. Without his encouragement, I wonder I would try the approach."

“...my supervisor played an important role in assisting my implementation of innovative approach. His comments and advices were essential to my further implementation."

"...of course, it is better to have a supervisor who can give me advices to help improving my implementation. The immediate comments will be very useful..."

“...more discussing with my supervisor will definitely help my implementation. His advices are usually practical and feasible..."

On the other hand, cooperating teachers might also act as hindrance factor if they did not support the implementation of TGfU. Student teachers usually seek help or advice from cooperating teachers if they have difficulties. Their supporting role in school is also important to the practice of TGfU. Some stated the influence of the cooperating teachers on their practice:

"My cooperating teacher did not agree with my implementation of TGfU approach and she suggested me not to adopt the approach during the teaching practice."

"I would seek comments from my cooperating teachers to see whether my TGfU approach had worked. I usually ask for his advice on space using and activities organizing..."

"My cooperating teacher did not know much about TGfU. She did not want me to try the approach. She thought it would be a waste of time if the students did not learn sports skill in the lessons."

Although there are some hindrance factors, the student teachers indicated that the positive students' responses reinforced their adoption of the approach:

"Students enjoyed the games, it does not matter what I teach, and they like the learning atmosphere; they initiated to take part in the activities..." “...the approach at least attracted the attention of the students; they really participated and learned in the games..."

"I find the approach is suitable for my students, they love and are willing to participate in $P E$ lessons..."

\section{Discussion}

Findings of the study hold implications for the preparation of physical education teachers with respect to the learning to teach TGfU process. The student teachers valued and learned to implement the TGfU approach within the teacher preparation programmes. They understood the concepts and teaching format of TGfU but they need to improve their knowledge of games designing and questioning skills in real practice. The trial teaching experiences enhanced their confidence in adopting the approach. However, what they learnt was insufficient for them to apply in real practice. Teacher educators pointed out that student teachers learned to teach by teaching (Cochran-Smith, \& Lytle, 1990). Student teachers need time to reflect and polish their practice by gaining more in-field experience. In order to provide better preparation of student teachers in adopting innovative methodologies, more opportunities in trying these approaches should be provided before the teaching practice.

The student teachers did encounter difficulties when learning to implement the TGfU approach as reported in other studies (Cruz, 2004; Cruz, Li, \& Kam, 2008; McNeill, et al., 2004). Similar teaching difficulties were mentioned by teachers when they first trying the TGfU approach (Cruz, 2004; Cruz, Li, \& Kam, 2008; DiazCueto, Hernandez-Alvarez, \& Castejon, 2010; McNeill, et al., 2004, McNeill, Fry, Wright, Tan, \& Rossi, 2008). Feeling insecure, the improper use of questions, lack of space and equipment, student misbehaviours and problems in designing games were usually recognized as teaching barriers when implementing the TGfU approach. Some student teachers did not know how to tackle these teaching difficulties and lost confidence. They eventually gave up adopting the approach at the end. Indeed, student teachers are usually facing teaching problems or concerns during their teaching practice (Behets, 1990; Cruz \& Chow, 1999; Hynes-Dusel, 1999; Moore, 2003; Zeichner \& Tabachnick, 1981). They are in need to have some support during this period. This implied that teacher educators should have responsibilities in helping 
them to overcome these common teaching problems. Supervisors and cooperating teachers might need to play more proactive roles in assisting the student teachers. In a recent study of studying the perceptions of relationship among members of student teaching triad, Murphy (2010) argued that both cooperating teachers and university supervisors could help to enhance professional development of student teachers during the teaching practice. Besides, physical education teacher educators should organize TGfU workshop and training to help cooperating teachers understand more about TGfU. This would definitely assist their giving advices to student teachers when implementing the approach. If student teachers are well prepared and supported to handle the teaching problems, more of them would adopt the approach in future.

Learning to teach TGfU requires more practice (Smith, 1991). Teaching practice is an important opportunity for student teachers to try the new teaching approach. Those who had tried the approach during teaching practice in the present study would like to adopt the approach in real school practice. This implied the experience of implementation would influence their future practice of the approach. If teacher educators strongly encourage and assist student teachers to try the TGfU approach, more of them would try and master the approach. One of the participants in the present study commented that if the TGfU approach was compulsory required to implement during the teaching practice, they would learn and implement the approach in a better way!

The results of the study also indicated that teaching practice is a valuable source of experience for student teachers to implement innovative approach and provide valuable information for physical education teacher educators. The student teachers who participated in the study expressed certain concerns when implementing TGfU that warrant attention. The results implied the responsibilities of the physical education teacher educators to continue address the preparation and ongoing professional development of physical educators.

\section{Conclusion}

Student teacher learned to implement the TGfU within the TGfU module and teaching practice. However, most of them faced some teaching difficulties when implementation. Some abdicated to solve the teaching problems and gave up trying the innovative approach. Teacher educators and cooperating teachers should play more important roles in helping them overcome the problems, otherwise student teachers may not try any innovative approach during teaching practice. This in turn may influence their confidence and practice of these approaches in future.

\section{References}

Attard, K., \& Armour, K. (2006). Reflecting on reflection: A case study on one teacher's early - career professional learning. Physical Education and Sport Pedagogy, 11(3), 209-229.

Bandura, A. (1986). Social foundations of though and action: A social cognitive theory. Englewood Cliffs, NJ: Prentice-Hall.

Behets, D. (1990). Concerns of preservice physical education teachers. Journal of Teaching in Physical Education, 10(1), 66-75.

Brown, S. I., Cooney, T. J., \& Jones, D. (1990). Mathematics teacher education. In W. R. Houston (Ed.), Handbook of research on teacher education (pp. 639-656). New York: Macmillan.

Bunker, D., \& Thorpe, R. (1982). A model for the teaching of games in the secondary school. Bulletin of Physical Education, 10, 9-16.

Cochran-Smith, M., Garfield, E., \& Greeberger, R. (1993) Student teachers and their teacher: Talking our way into new understandings. In N. A. Branscombe, D. Goswami, \& J. Schwartz (Eds.), Student teaching teachers learning (pp. 274-295). Portsmouth, NH: Heinemann.

Cochran-Smith, M., \& Lytle, S. (1990). Research on teaching and teacher research: The issues that divide. Educational Researcher, 19(2), 2-11.

Cohen, L., Manion, L., \& Morrison, K. (2000). Research methods in education ( ${ }^{\text {th }}$ ed.). London: Routledge and Falmer.

Copeland, W. D., Birmingham, C., de la Cruz, E., \& Lewin, B. (1993). The reflective practitioner in teaching: Toward a research agenda. Teaching and Teacher Education, 9(4), 347-359. 
Cruz, A. (2004). Teachers' and students' perceptions of teaching games for understanding approach in physical education lesson. Journal of Physical Education \& Recreation (Hong Kong), 10(2), 57-66.

Cruz, A., \& Chow, W. (1999). Concerns on the Preservice and In-service Primary Physical Education Student Teachers. Journal of Physical Education \& Recreation (HK), 5(2), 10-16.

Cruz, A., Li, C., \& Kam, W. K. (2008, October). Learning to implement Teaching Games for Understanding. Paper presented at the $2^{\text {nd }}$ International Conference: Current issues and new ideas in sport science, Kaunas, Lithuania, Lithuanian Academy of Physical Education.

Darling-Hammond, L. (1998). Teacher learning that supports student learning. Educational Leadership, 55(5), 6-11.

Diaz-Cueto, M., Hernandez-Alvarez, J. L., \& Castejon, F. J. (2010). Teaching games for understanding to inservice physical education teachers: Rewards and barriers regarding the changing model of teaching sport. Journal of Teaching in Physical Education, 29(4), 378-398.

Glaser, B. G., \& Strauss, A. L. (1967). The discovery of grounded theory: Strategies for qualitative research. New York: Aldine de Gruyter.

Glenwright, P. (2001). Towards a competency-based quality assurance framework for field experience: a preliminary review of established models of teacher education. Paper presented at the HKIEd Field Experience Symposium, Hong Kong, The Hong Kong Institute of Education.

Goodlad, J. I. (1984). A place called school. New York: McGraw-Hill.

Griffin, L. L., Brooker, R., \& Patton, K. (2005). Working towards legitimacy: Two decades of Teaching Games for Understanding. Physical Education and Sport Pedagogy, 10(3), 213-223.
Gurvitch, R., Blankenship, B. T., Metzler, M., \& Lund, J. (2008). Student teachers' implementation of ModelBased Instruction: Facilitators or Inhibitors. Journal of Teaching in Physical Education, 27(4), 466-486.

Hynes-Dusel, J. M. (1999). Physical education student teacher concerns. The Physical Educator, 56(1), 3348.

Jalongo, M., \& Isenberg, J. (1995). Teachers' stories. San Francisco: Jossey-Bass.

Korthagen, F. A. J. (2001) (Ed.). Linking practice and theory: The pedagogy of realistic teacher education. Mahwah: Lawrence Erlbaum associated.

Lee, H. J. (2005). Understanding and assessing pre-service teachers' reflective thinking. Teaching and Teacher Educator, 21(6), 699-715.

Li, C., \& Cruz, A. (2006). Learning to teaching games for understanding: Experiences from four pre-service PE teachers in the Hong Kong Institute of Education. In R. Liu, C. Li., \& A. Cruz (Eds). Teaching games for understanding in the Asia-Pacific region (pp. 25-36). Hong Kong: The Hong Kong Institute of Education.

Lincoln, Y., \& Guba, E. (1985). Naturalistic inquiry. Beverly Hills. CA: Sage.

Mayes, C. (2001). Deepening our reflectivity. Teacher Educator, 36(4), 248-264.

McCaughtry, N., Sofo, S., Rovegno, I., \& CurtnerSmith, M. (2004). Learning to teach sport education: Misunderstandings, pedagogical difficulties, and resistance. European Physical Education Review, 10(2), 135-155.

McNeill, M. C., Fry, J. M., Wright, S. C., Tan, W. K. C., \& Rossi, T. (2008). Structuring time and questioning to achieve tactical awareness in games lessons. Physical Education and Sport Pedagogy, 13(3), 231-249. 
McNeill, M. C., Fry, J. M., Wright, S. C., Tan, W. K. C., Tan, K. S. S., \& Schempp, P. G. (2004). In the local context: Singaporean challenges to teaching games on practicum. Sport, Education and Society, 9(1), 3-32.

Melograno, V. J. (1998). Professional and student portfolios for physical education. Champaign, IL: Human Kinetics.

Moore, R. (2003). Reexamining the field experiences of preservice teachers. Journal of Teacher Education, 54(1), 31-42.

Murphy, K. L. (2010). Perceptions of the student teaching triad: An inquiry into relationships and supervision. Asian Journal of Physical Education \& Recreation, 16(1), 53-66.

Murray-Harvey, R., Slee, P. T., Lawson, M. J., Silins, H., Banfield, G., \& Russel, A. (2000). Under stress: The concerns and coping strategies of teacher education students. European Journal of Teacher Education, 23(1), 19-35.

Placek, J. H., \& Smyth, D. M. (1995). Teaching preservice physical education teachers to reflect. The Physical Educator, 52(2), 106-112.

Senne, T. A., \& Rikard, G. L. (2004). A developmental intervention via the teaching portfolio: Employing the teaching/learning framework. Journal of Teaching in Physical Education, 23(1), 88-104.

Silverman, D. (1993). Interpreting qualitative data: Methods for analyzing talk, text and interaction. London: Sage.
Smith, M. D. (1991). Utilizing the games for understanding model at the elementary school level. The Physical Educator, 48(4), 184-187

Strauss, A. L., \& Corbin, J. (1990). Basics of qualitative research: Grounded theory, procedures and techniques. Newbury Park: Sage Publication.

Tsangaridou, N. (2005). Classroom teachers' reflection on teaching physical education. Journal of Teaching in Physical Education, 24(1), 24-50

Tsangaridou, N., \& Siedentop, D. (1995). Reflective teaching: A literature review. Quest, 47(2), 212-237.

Wang, C. L., \& Ha, A. (2009). Pre-service teachers' perception of teaching games for understanding: A Hong Kong perspective. European Physical Education Review, 15(3), 407-429.

Zeichner, K., \& Tabachnick, B. R. (1981). Are the effects of university teacher education washed out by school experiences? Journal of Teacher Education, 32(3), 711.

\section{Correspondence:}

Contact Person: Dr. Alberto Cruz

聯絡人: 高達倫博士

電話 Telephone: (852) 29487847

傳真 Fax: (852) 29487848

電郵 E-mail: acruz@ied.edu.hk 